April 2011

\title{
Team America: Genocide Prevention?
}

Uğur Ümit Üngör

Follow this and additional works at: https://digitalcommons.usf.edu/gsp

\section{Recommended Citation}

Üngör, Uğur Ümit (2011) "Team America: Genocide Prevention?," Genocide Studies and Prevention: An International Journal: Vol. 6: Iss. 1: Article 4.

Available at: https://digitalcommons.usf.edu/gsp/vol6/iss1/4

This Articles is brought to you for free and open access by the Open Access Journals at Digital Commons @ University of South Florida. It has been accepted for inclusion in Genocide Studies and Prevention: An International Journal by an authorized editor of Digital Commons @ University of South Florida. For more information, please contact digitalcommons@usf.edu. 


\title{
Team America: Genocide Prevention?
}

\author{
Uğur Ümit Üngör \\ Assistant Professor, Department of History, Utrecht University
}

\section{Introduction}

Genocide can be defined as a complex process of systematic persecution and annihilation of a group of people by a government. In the twentieth century, approximately 40 to 60 million defenseless people became victims of deliberate genocidal policies. The twenty-first century did not begin much better, with genocidal episodes going on in Darfur and the Congo. We can speak of genocide when individuals are persecuted and murdered merely on the basis of their presumed or imputed membership in a group rather than on their individual characteristics or participation in certain acts. Although it makes little sense to define genocide by a specific number of victims affected by it, we can state that a genocidal process always concerns a society at large and that genocide destroys a significant and often critical part of the affected community. It can be argued that genocidal processes are particularly malicious and destructive because they are directed against all members of a group, most often against innocent and defenseless people who are persecuted and killed regardless of their behaviour. Genocide always denotes a colossal and brutal collective criminality. For this reason, genocide has been studied as a modern phenomenon that is distinct from other forms of mass violence. After Raphael Lemkin died in 1959, the term seemed to be a dead letter. But in the 1970s historians and social scientists rediscovered the concept and published the first academic work on genocide. Since then, the number of publications has grown and today genocide studies, with journals and research institutes in North America and Europe, is a respectable intellectual specialism. ${ }^{1}$

Three questions are central in this research field. First, what are the causes of a genocidal process? Or, put another way, how does the systematic destruction of a group of people begin? Second, how does a genocidal process develop? There are strong indications that, when such a process has been put in motion, it develops its own dynamic. How does that process evolve from the individual to the collective level? Finally, it is important to investigate the consequences of genocide. How are perpetrators, victims, and third parties affected by genocide? How do they process, if at all, the traumatic events? In the growing, interdisciplinary field of genocide studies much useful research has been conducted into the evolution of separate genocides such as the destruction of Ottoman Armenians in 1915, the Holocaust, and the genocides in Cambodia from 1975 to 1979, Rwanda in 1994, and Bosnia during the Yugoslav civil wars. A significant amount of knowledge about certain aspects of genocide exists as well. Both separate and comparative research has been conducted, for instance, on the turn of a fairly "normal" civil society into a persecutory one, the motives of the ordinary people who are involved in mass murders, the power and effect of charismatic leaders, and aspects of violence as they relate to gender. From time to time, publications appear trying to understand the causes of genocide in 
order to integrate that knowledge into policy mechanisms aimed at the prevention of genocide. Such a report, MARO: Mass Atrocity Response Operations; A Military Planning Handbook, was published by the US army and attempts to build on this tradition.

\section{MARO: Fallacies, Missteps, Naiveté}

It is important for military personnel across the world to understand genocidal situations. Clusters of perpetrators need to be told that they can be held accountable for their actions and that the old excuse of "orders are orders" (Befehl ist Befehl) is not exculpatory. It is crucial for intervention forces to recognize a genocidal situation because of the nature and purpose of their work. For example, during the separation of Muslim men from women and children in Srebrenica, the Dutch UN officials should have immediately understood that this action was a pernicious omen if not a direct indicator of mass murder to come. Historically, the gender segregation of groups of unarmed civilians has not led to the containment or de-escalation of the conflict; in fact, it has served little other purpose than further destruction. For this reason, in principle, a handbook such as $M A R O$ is a laudable effort. However, genocide is a political act, not one that can be simply understood and tackled through a purely military prism. Most of the handbook's flaws emanate from its inability to integrate the political dimension of genocide into its report. In the analysis that follows I will confront this report with existing genocide theory as well as several concrete scenarios.

There are some bizarre passages in the handbook. For example, when discussing victims the report states the obvious: "Victims will probably require significant humanitarian assistance and will likely desire to return to their land, seek justice and/ or retribution against the perpetrators, and gain knowledge of what happened to family members or acquaintances who may have disappeared during the crisis."2 More importantly, the handbook insufficiently discusses the problem of state sovereignty. For example, the handbook develops the idea that decisions need to be made "whether to target, pursue, or prosecute perpetrators, which potentially could mean that the MTF [MARO Task Force] would need to attack the HN [host nation] military or government" (60). Does this mean that the United States, in an effort to stop genocide in Darfur, would declare war on Sudan-a major ally of China? Or would an elite unit in a helicopter secretly land in Khartoum, sneak into the presidential palace, and assassinate Omar Al-Bashir? This scenario is taken straight from the latest Rambo film, in which Stallone and a clutch of mercenaries infiltrate the Burmese jungle and liberate a group of victims. In other words, the ambitions laid out in this handbook challenge the imagination of the social scientist.

Having worked on genocide perpetrators in my past research, I wish to present some thoughts on the report's (mis)understanding of perpetration. ${ }^{3}$ The obvious example is paramilitarism. According to the report, perpetrators are a clearly definable, easily identifiable group of killers. But comparative research into the involvement of paramilitary units in mass crimes, such as genocide and ethnic cleansing, demonstrates that governments benefit from relying on paramilitary groups as they provide governments with plausible deniability for the violence that units commit against targeted populations. The regime can simply disavow any linkage with the paramilitary organizations by claiming that they operated on their own volition. ${ }^{4}$ This model fits virtually every case of genocide in the twentieth century. Although the report acknowledges the different types of perpetrators (paramilitaries, military, top state elites, and so forth), it fails to recognize the fundamentally different political contexts 
in which they operate. Intervening in a situation where a breakaway rebel group is persecuting a group in a limited territory requires following entirely different procedures than a situation in which the very political top is involved in the organization of violence (44-45). Deploying a well-armed force to stop massacres against Banyamulenge civilians in the Eastern Congo may be relatively easy. After all, the Congo is a failed state in an advanced stage of decomposition and its resistance as host nation might be negligible. But there are three not unrealistic scenarios for future conflict. All of the three examples to follow build on recent violent events that captured the attention of newspaper readers throughout the world.

The first example is China's persecution of the Uighur population of Xinjiang. The ongoing marginalization and persecutions, the Uighur reaction and riots, and the ensuing backlash by the government have demonstrated that violence against civilians is not considered a serious transgression by the Chinese government. Should the persecution increase intensively as well as extensively into collective dispossession, displacement, and the murder of elites, China's Uighurs would face extremely bleak prospects. During the riots in early July 2009 more than 100 Uighurs were killed, 1,700 injured, and an unknown number "disappeared." What is particularly relevant is that the Chinese government did not only arrest and imprison Uighurs in Urumqi (where the riots had taken place), but also in other cities including Kashgar. ${ }^{5}$ This potentially signifies ethno-categorical thinking by the Chinese security forces, which constitutes a serious and radical development. After these arrests and killings, no amount of protest from NGOs or governments made a serious impact on the Chinese government's policies in regards to the Uighurs.

A second example comes from the Gaza Strip. In a wide-ranging comparative study of ethnic cleansing, Michael Mann included the Palestinians, especially those in the Gaza Strip, in a select group of victimized communities that are facing a slow but imminent process of persecution and drifting in the long term toward critical decline if not destruction. ${ }^{6}$ A recent example of asymmetrical violence in the IsraeliPalestinian conflict is the 2008 to 2009 Gaza Winter War. The UN report produced by Richard Goldstone concluded that Hamas committed violations of the laws of war and other war crimes and that the Israeli army had used disproportionate force, targeting Palestinian civilians and destroying civilian infrastructure. The war ended in the very asymmetrical body count of 1,417 Palestinian and 13 Israeli deaths. ${ }^{7}$ To any dispassionate scholar of mass violence, these figures and the dynamic of the violence must be interpreted as unmistakable signs of an escalating counterinsurgency potentially heading toward catastrophe. The issue is not so much the discriminatory population policies of the Israeli government-these measures are being sharply criticized and satirized in Israeli society. The real issue is the asymmetry of violence, which can polarize even further. ${ }^{8}$

The final example comes from Chechnya. Whether under Russian imperial or federal rule, from a long-term perspective, the North Caucasus has been a thorn in the side of Russian political elites. ${ }^{9}$ The March 2010 suicide bombings in the Moscow subway sparked a sharp radicalization of a conflict that has been lingering since the eruption of the first war in 1994. On the part of the Chechens, the ruthlessness of these attacks also denotes an awareness of the asymmetrical nature of the conflict, a sense of collective despair, an acceptance of blind revenge, and a lack of belief in future prospects of mutual reconciliation, conflict de-escalation, and societal integration. This conflict escalated to such an extent that in May 2001 the Committee on Conscience of the United States Holocaust Memorial Museum placed Chechnya on its Genocide Alert list. ${ }^{10}$ Here too, the asymmetry of the conflict is striking: 
although the Chechen rebels targeted both Russian soldiers and civilians, the total losses they suffered far exceed those of the Russian military campaign. In a comparative study of ethnic cleansing, Norman Naimark expressed fear that Chechnya may be on the brink of genocide if the conflicts in the Caucasus deepen. ${ }^{11}$

In all three cases, a militarily and politically superior state attacked a vulnerable minority that included not only political elites (whatever their political colouring) but many civilians as well. In all three cases, recent conflagrations fit in a pattern of long-term disempowerment and persecution from the early- and mid-twentieth century. Now, if we believe $M A R O$, there are several strategies to tackle these cases successfully: saturation, oil spot, separation, safe areas, partner enabling, containment, defeat perpetrators (70-85). How would future escalations in similar scenarios be stopped? Turn Gaza into a safe area after the flotilla scene? Deploy forces in Urumqi and use the method of the oil spot? (Operation Deepwater Horizon?) Demilitarize the Caucasus, a major source of Russia's internal and external security policy? None of these constraints and problems is discussed in a satisfactory way in the handbook. In Annex F ("Intelligence Considerations"), the handbook does, however, pose questions for the "intelligence personnel to assist their analysis of the MARO environment" (118). Let us consider these questions in a hypothetical, but not unthinkable, new phase of a serious escalation of mass violence in Chechnya:

1. Who are the perpetrators? Vladimir Putin and Dmitry Medvedev

2. Where are they located?

The Kremlin

3. How are they organized?

In the Russian domestic secret service, FSB, which has eleven departments and directorates

4. What are their usual modes of operation? Counterintelligence, counter-terrorism, border protection, export control

5. What are their capabilities and vulnerabilities? They are capable of anything and vulnerable to little.

6. What are their objectives and ideology? "[We will] eliminate them [terrorists] like rats." 12

7. What are their recent and current activities?

Appointing Ramzan Kadyrov as President of Chechnya and unconditionally endorsing his policies of murder, extortion, embezzlement, intimidation, rape, forced disappearance, torture, and other acts of violence against civilians

8. What support mechanisms exist to sustain their operations? Spetsnaz and organized crime

9. What are their possible courses of action and which of these will likely be taken?

Burn villages, massacre civilians, bomb buildings, and destroy property.

10. What is the level of government complicity with the perpetrators? Full

11. Are there any divisions among the perpetrators?

Not anymore

The tragicomic absurdity of the situation is clear: the handbook does not offer a serious and credible way of intervening in possible escalations of real crises.

Another important issue is the relationship between domestic support (i.e., political will) and foreign policy. Nowhere in the report is there any discussion of 
the relationship between American political dynamics and a MARO. How will the use of funds be justified to the population or to parliament? Moreover, there is no sensible explanation of how a MARO would function in the case that an ally of the United States would commit mass atrocities. Mann has argued that "the United States is currently intervening on the side of dominant states against their ethnicreligious insurgents. From Palestine to Georgia, to Chechnya, to Kashmir, to the southern Philippines, to Colombia, U.S. policy favors state terrorists." 13 Without a critical discussion of this problem, one cannot take the handbook seriously.

\section{Conclusion}

Two proverbs and a quote capture the essence of MARO. To begin with, a German proverb suits the handbook well: "Well meant is not always well done" (Gut gemeint ist nicht immer gut gemacht). Although the handbook means well, it commits the sin of utter naïveté in its assumptions and hence also in its conclusions. Secondly, reading it immediately invokes the Turkish proverb "Calculations at home won't match the market" (Evdeki hesap çarşıya uymaz) or Moltke the Elder's famous saying "No battle plan survives contact with the enemy." In other words, if we believe the handbook, the eight scenarios outlined in $M A R O$ are predictable and will seamlessly conform to conditions on the ground. All in all, the handbook cannot see the forest for the trees. It is full of excessive detail and out of touch with reality. It might have been much more useful to take real historical or current events and analyze them in light of two or three potential future developments. What we need is not a desk fantasy about how to curb hypothetical "mass atrocities" but (a) credible argumentation linking military planning with international politics and (b) thorough analysis of existing genocidal processes, such as Darfur. For instance, the failures of the 1999 NATO bombing of Serbia during the Kosovo War-the bombing escalated the atrocities rather than stopped them-could have been scrutinized carefully. But, instead, the handbook very briefly refers to airpower only at the end and does not seriously consider it as a form of action.

$M A R O$ is also ridden with obscure jargon, vague abstractions, incredible non sequiturs, caricatural acronyms you forget after a few paragraphs, fictional scenarios seemingly drawn from a computer game, ambitious flowcharts that only serve to elicit roaring laughter, and naïve assumptions about international relations. One can read page after page and still not understand what the report intends to convey to the reader or where it is heading in general. Some passages are worthwhile, but further probing demonstrates that it is difficult to intellectually engage with this naïve military-planning document for genocide prevention because genocide is embedded in political structures. In order to verify the military recommendations and commentary in the handbook, one likely needs to approach military sociologists for their expert opinions.

An unforgivable sin that the handbook commits is that it searches for that one single solution that will serve as a panacea for all evil, a deus ex machina that will intervene and stop genocide. Ultimately, this will accomplish the utopia of a genocide-free world. This is an ideology that ignores the pragmatic arguments marshalled by specialists in the field of conflict prevention. ${ }^{14}$ Unfortunately, more realistic and sober accounts of genocide recognize that such an elixir does not exist. We need to recognize that political violence will continue to play a part within and between human societies. As Jacques Sémelin has reminded us in his penetrating study of genocide, "We are really going down the road of formulating a superbly pious wish: because conflict is obviously inherent in the history of man, and so any 
intention to prevent it is doomed to fail from the start." 15 No early-warning system, preventive diplomacy, rapid response unit, structural prevention, MARO, or other well-meant effort can fully extinguish our potential for mass violence.

The handbook ties in with many themes in Daniel Goldhagen's recent documentary film with the dubious title Worse than War. (Apropos, really? Is genocide worse than war? In other words, if I would write a book on the enormous destruction of human lives and property wrought by a war, would I title it Better than Genocide?) In the film, Goldhagen ignores the thorny issue of state sovereignty and travels across the world to preach American military invasion as the most effective form of genocide prevention. As in the book with the same title, the documentary does not deploy any dynamic political science model but uses static binaries of bad guys versus good guys. Destroying the bad guys will pave the way for the genocide-free, multiethnic Walhalla to which we aspire. This is a complete failure to recognize the fact that there is a lot that we do not understand about mass murder yet. The film compensates for this lack of intellectual sophistication with an overdose of moralistic indignation about the phenomenon rather than dispassionate reflection. (Moreover, the documentary grossly exaggerates the supposed threats that emanate from Muslim parts of the world and from current Islamist terrorism. Ironically, in the three examples provided above, it is mostly Muslims who are living under threat of collective victimization.)

Viewed from this broader perspective, MARO truly seems to be a reflection of its time and political culture. Well-intentioned do-gooders in the West often do not grasp the complexity of the many processes that occur during genocide. They insufficiently recognize the difficulty of being able to grasp, let alone control, the international minefield of states and the outcome of this constellation. The handbook's reasoning denotes a certain blind belief in the formability of the world through a series of measures that can shape the future. Its credibility, however, is critically undermined by the authors' naïve views on global power relations. The authors believe in a world in which everything is feasible and they have answers to every possible human problem. The handbook suffers from a lack of modesty and instead surrenders to a blind conviction in the otherwise laudable goal of genocide prevention. Most of all, the authors also turn a blind eye to the politics of a MARO itself. Will not such a phenomenon become the object of political manipulation? And what if American forces are the ones committing the atrocities?

Nothing epitomizes this intransigence better than the last scenario described in $M A R O$, "Defeat the Perpetrator." Under this heading, the handbook actually includes the reference "Iraq 2003 model." With the 106,035 civilian deaths in Iraq in mind, ${ }^{16}$ one can hardly be surprised that the US army has produced a report this credulous. Surely its annual budget of more than $\$ 660$ billion could be spent in a more prudent way. All in all, the handbook fails to understand that in the international state system states are allied and profoundly interconnected to each other through a series of economic, political, and security interests. Intervention into the interests of one state means manipulation or influence of other states' interests as well. The simplistic thought processes deployed in this handbook fail to convince this reader of its usefulness in an intervention in a genocidal process.

\section{Notes}

1. For three recent volumes taking stock of the state of affairs in the research field, see Dan Stone, ed., The Historiography of Genocide (Basingstoke: Palgrave Macmillan, 2008); Samuel Totten and Paul R. Bartrop, eds., The Genocide Studies Reader (New York: 
Routledge, 2009); Donald Bloxham and A. Dirk Moses, eds., Oxford Handbook of Genocide Studies (Oxford: Oxford University Press, 2010).

2. Sarah Sewall, Dwight Raymond, and Sally Chin, MARO: Mass Atrocity Response Operations; A Military Planning Handbook (Cambridge, MA: Harvard Kennedy School / Carr Centre for Human Rights Policy, 2010), 47; emphasis added. Subsequent references appear parenthetically in the text.

3. See, for example, Uğur Ümit Üngör, "Diyarbekir (1915-1916): Young Turk Mass Killings at the Provincial Level," Online Encyclopedia of Mass Violence, 25 March 2009, http://www.massviolence.org/The-genocidal-process-in-the-southeastern-Ottoman-province.

4. Alex Alvarez, "Militias and Genocide," War Crimes, Genocide, and Crimes against Humanity 2 (2006): 1-33.

5. Amnesty International, "Justice, Justice": The July 2009 Protests in Xinjiang, China (London: Amnesty International Publications, 2010), 20.

6. Michael Mann, The Dark Side of Democracy: Explaining Ethnic Cleansing (Cambridge: Cambridge University Press, 2004), 520.

7. Richard Goldstone, Report of the United Nations Fact-Finding Mission on the Gaza Conflict (New York: United Nations General Assembly, 2009).

8. See the excellent discussion in Michael L. Gross, Moral Dilemmas of Modern War: Torture, Assassination, and Blackmail in an Age of Asymmetric Conflict (Cambridge: Cambridge University Press, 2010), 253-63.

9. Vicken Cheterian, War and Peace in the Caucasus: Ethnic Conflict and the New Geopolitics (London: Hurst, 2008), 222-33.

10. Emma Gilligan, Terror in Chechnya: Russia and the Tragedy of Civilians in War (Princeton, NJ: Princeton University Press, 2009), 1.

11. Norman Naimark, Fires of Hatred: Ethnic Cleansing in Twentieth-Century Europe (Cambridge, MA: Harvard University Press, 2002), 107.

12. Vladimir Putin (speech, Federal Security Service, Moscow, February 7, 2006), quoted in "Putin Accuses NGOs of Being Unscrupulous about Their Funding," Kyiv Post, 7 February 2006, http://www.kyivpost.com/news/world/detail/23826/.

13. Mann, The Dark Side of Democracy, 526.

14. Arthur C. Helton, The Price of Indifference: Refugees and Humanitarian Action in the New Century (Oxford: Oxford University Press, 2002), 284.

15. Jacques Sémelin, Purify and Destroy: The Political Uses of Massacre and Genocide (London: Hurst, 2007), 364.

16. “Iraq Body Count," accessed 3 August 2010, http://www.iraqbodycount.org. 